\title{
SYNTHESIS OF 1,3-DIPHENYLTRIAZENIDE COMPLEXES OF ALUMINIUM, GALLIUM AND INDIUM : CRYSTAL STRUCTURE OF TRIS(1,3-DIPHENYLTRIAZENIDO)ALUMINIUM(III)
}

\author{
JOHN T. LEMAN and ANDREW R. BARRON*
}

Chemical Laboratories, Harvard University, Cambridge, MA 02138, U.S.A.

and

\section{JOSEPH W. ZILLER}

Department of Chemistry, University of California, Irvine, CA 92717, U.S.A.

and

\section{ROBERT M. KREN}

Department of Chemistry, University of Michigan-Flint, Flint, MI 48502, U.S.A.

(Received 26 January 1989 ; accepted 21 February 1989)

\begin{abstract}
The reaction of $\mathrm{AlMe}_{3}$ with 1,3-diphenyltriazene [Hdpt] in toluene gives $\mathrm{Al}(\mathrm{dpt})_{3}$, even when $\mathrm{AlMe}_{3}$ is in large excess. The monomeric structure has been established by Xray diffraction. Crystals of $\mathrm{Al}(\mathrm{dpt})_{3}$ are monoclinic, space group $C 2 / c$ with $a=20.587(3)$, $b=16.005(3), c=13.236(3) \AA$ and $\beta=119.172(12)^{\circ}, Z=4, R=0.067$ and $R_{\mathrm{w}}=0.083$. The aluminium(III) is coordinated by three chelating triazenido ligands to give a trigonally distorted octahedral geometry. The gallium and indium analogues are also reported.
\end{abstract}

The triazenide anion, $\mathrm{RN}=\mathrm{N}-\mathrm{NR}^{-}$, might be expected to display a variety of coordination modes. Transition metal complexes containing monodentate (1), chelate (2) and bridging (3) triazenide ligands have been reported, ' suggesting a formal analogy to the carboxylate anion, $\mathrm{O}=\mathrm{C}(\mathrm{R})-\mathrm{O}^{-}$. Despitc this analogy and the wide range of Group III carboxylates reported in the literature, ${ }^{2}$ the only examples of Group III triazenides are $\mathrm{Tl}(\mathrm{dpt})_{3}$ (Hdpt $=1,3$-diphenyltriazene) and $\mathrm{Tl}(\mathrm{ppt})_{3}$ (Hppt = 1-phenyl-3-(2'-pyridyl)triazene), which were characterized as tris-chelate complexes by IR spectroscopy, ${ }^{3}$ and the dimeric $[\mathrm{Tl}(\mathrm{dpt})]_{2}$ whose structure was determined by X-ray crystallography. ${ }^{4}$
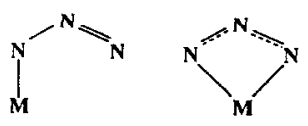

(1)

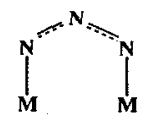

(3)
* Author to whom correspondence should be addressed.
We now report the synthesis and characterization of the tris(1,3-diphenyltriazenido)aluminium(III), gallium(III) and indium(III) complexes.

\section{RESULTS AND DISCUSSION}

The complex $\mathrm{Al}(\mathrm{dpt})_{3} \quad(\mathrm{Hdpt}=1,3$-diphenyltriazene) was first obtained in low yield from the reaction of $\mathrm{AlCl}_{3}$ with $\mathrm{Li}(\mathrm{dpt})$. An improved procedure, however, is the direct reaction of Hdpt with $\mathrm{AlMe}_{3}$ in toluene.

The compound $\mathrm{Al}(\mathrm{dpt})_{3}$ has been fully characterized by elemental analysis and spectral data. The ${ }^{1} \mathrm{H}$ NMR spectrum, in $\mathrm{CDCl}_{3}$, shows an $\mathrm{A}_{2} \mathrm{~B}_{2} \mathrm{C}$ pattern for the monosubstituted phenyl groups, indicating that the triazenides are either fluxional on an NMR time scale, or in a symmetrical environment. The ${ }^{27} \mathrm{Al} \mathrm{NMR}$ spectrum consists of a broad peak whose shift $(\delta=25 \mathrm{ppm})$ is indicative of a six-coordinate aluminium centre, ${ }^{5}$ but is extremely broad $\left(w_{1 / 2}=1160 \mathrm{~Hz}\right)$, possibly exacerbated by coupling to the quadrupolar ${ }^{14} \mathrm{~N}$ nuclei. The IR 


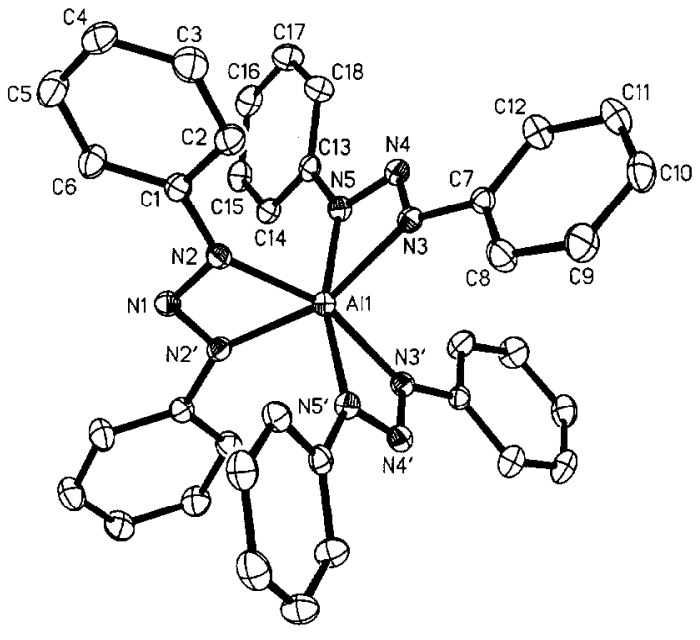

Fig. 1. Molecular structure of $\mathrm{Al}(\mathrm{dpt})_{3}$ showing the atom numbering; hydrogen atoms are omitted for clarity. spectrum shows bands at 1320 and $1295 \mathrm{~cm}^{-1}$, which are characteristic of chelating triazenide groups. ${ }^{1}$ The chelating coordination mode has been confirmed by $\mathrm{X}$-ray crystallography.

The structure of $\mathrm{Al}(\mathrm{dpt})_{3}$ is shown in Fig. 1; selected bond lengths and angles are given in Table 1. One disordered molecule of toluene per $\mathrm{Al}(\mathrm{dpt})_{3}$ is present in the lattice as a solvent of crystallization (see Experimental). The molecule of $\mathrm{Al}(\mathrm{dpt})_{3}$ has a two-fold crystallographic axis passing through $\mathrm{Al}(1)$ and $\mathrm{N}(1)$. The aluminium is in a trigonally distorted octahedral environment, which is consistent with the ${ }^{27} \mathrm{Al}$ NMR spectrum.

The average $\mathrm{Al}-\mathrm{N}$ distance $(1.972(5) \AA)$ is within the range previously observed for $\mathrm{Al}-\mathrm{N}$ bonds $(1.88-2.09 \AA),{ }^{6}$ however, the small $\mathrm{N}-\mathrm{Al}-\mathrm{N}$ angles $\left(64.1(2)-64.2(2)^{\circ}\right)$ suggest that the chelate ring is under considerable strain. The simi-

Table 1. Selected bond lengths $(\AA)$ and angles $\left(^{\circ}\right)$ of $\mathrm{Al}(\mathrm{dpt})_{3}$

\begin{tabular}{|c|c|c|c|}
\hline $\mathrm{Al}(1)-\mathrm{N}(2)$ & $1.972(4)$ & $\mathrm{Al}(1)-\mathrm{N}(3)$ & $1.977(4)$ \\
\hline $\operatorname{Al}(1)-N(5)$ & $1.968(5)$ & $\mathrm{N}(1)-\mathrm{N}(2)$ & $1.316(4)$ \\
\hline$N(2)-C(1)$ & $1.411(5)$ & $N(3)-N(4)$ & $1.315(6)$ \\
\hline$N(3)-C(7)$ & $1.413(5)$ & $N(4)-N(5)$ & $1.314(4)$ \\
\hline$N(5)-C(13)$ & $1.407(7)$ & $C(1)-C(2)$ & $1.398(6)$ \\
\hline$C(1)-C(6)$ & $1.375(7)$ & $C(2)-C(3)$ & $1.389(6)$ \\
\hline$C(3)-C(4)$ & $1.380(8)$ & $C(4)-C(5)$ & $1.378(7)$ \\
\hline$C(5)-C(6)$ & $1.375(7)$ & $C(7)-C(8)$ & $1.380(9)$ \\
\hline$C(7)-C(12)$ & $1.379(8)$ & $C(8)-C(9)$ & $1.379(7)$ \\
\hline$C(9)-C(10)$ & $1 . .378(9)$ & $C(10)-C(11)$ & $1.377(10)$ \\
\hline$C(11)-C(12)$ & $1.381(7)$ & $C(13)-C(14)$ & $1.398(5)$ \\
\hline$C(13)-C(18)$ & $1.383(8)$ & $C(14)-C(15)$ & $1.384(9)$ \\
\hline$C(13)-C(16)$ & $1.381(10)$ & $C(16)-C(17)$ & $1.379(6)$ \\
\hline$C(17)-C(18)$ & $1.385(9)$ & & \\
\hline$N(2)-A l(1)-N(3)$ & $101.1(1)$ & $\mathrm{N}(2)-\mathrm{Al}(1)-\mathrm{N}(5)$ & $93.3(2)$ \\
\hline $\mathrm{N}(3)-\mathrm{Al}(1)-\mathrm{N}(5)$ & $64.2(2)$ & $\mathrm{N}(2)-\mathrm{Al}(1)-\mathrm{N}\left(2^{\prime}\right)$ & $64.1(2)$ \\
\hline $\mathrm{N}(3)-\mathrm{Al}(1)-\mathrm{N}\left(2^{\prime}\right)$ & $160.3(2)$ & $\mathrm{N}(5)-\mathrm{Al}(1)-\mathrm{N}\left(2^{\prime}\right)$ & $102.2(2)$ \\
\hline $\mathrm{N}(3)-\mathrm{Al}(1)-\mathrm{N}\left(3^{\prime}\right)$ & $96.1(2)$ & $\mathrm{N}(5)-\mathrm{Al}(1)-\mathrm{N}\left(3^{\prime}\right)$ & $103.0(2)$ \\
\hline$N(5)-A l(1)-N\left(5^{\prime}\right)$ & $161.8(2)$ & $\mathrm{N}(2)-\mathrm{N}(1)-\mathrm{N}\left(2^{\prime}\right)$ & $105.2(4)$ \\
\hline $\mathrm{Al}(1)-\mathrm{N}(2)-\mathrm{N}(1)$ & $95.4(2)$ & $\mathrm{Al}(1)-\mathrm{N}(2)-\mathrm{C}(1)$ & $147.0(3)$ \\
\hline$N(1)-N(2)-C(1)$ & $116.4(3)$ & $\mathrm{Al}(1)-\mathrm{N}(3)-\mathrm{N}(4)$ & $94.9(2)$ \\
\hline $\mathrm{Al}(1)-\mathrm{N}(3)-\mathrm{C}(7)$ & $146.5(4)$ & $\mathrm{N}(4)-\mathrm{N}(3)-\mathrm{C}(7)$ & $117.8(4)$ \\
\hline$N(3)-N(4)-N(5)$ & $105.6(4)$ & $\mathrm{Al}(1)-\mathrm{N}(5)-\mathrm{N}(4)$ & $95.3(3)$ \\
\hline $\mathrm{Al}(1)-\mathrm{N}(5)-\mathrm{C}(13)$ & $145.8(3)$ & $N(4)-N(5)-C(13)$ & $117.8(4)$ \\
\hline$N(2)-C(1)-C(2)$ & $117.9(4)$ & $\mathrm{N}(2)-\mathrm{C}(1)-\mathrm{C}(6)$ & $122.9(4)$ \\
\hline$C(2)-C(1)-C(6)$ & 119.1(4) & $C(1)-C(2)-C(3)$ & $119.5(5)$ \\
\hline$C(2)-C(3)-C(4)$ & $120.5(4)$ & $C(3)-C(4)-C(5)$ & $119.6(5)$ \\
\hline$C(4)-C(5)-C(6)$ & $120.2(5)$ & $C(1)-C(6)-C(5)$ & $121.1(4)$ \\
\hline$N(3)-C(7)-C(8)$ & $118.1(5)$ & $N(3)-C(7)-C(12)$ & $122.9(5)$ \\
\hline$C(8)-C(7)-C(12)$ & $118.9(4)$ & $C(7)-C(8)-C(9)$ & $120.7(6)$ \\
\hline$C(8)-C(9)-C(10)$ & $120.1(7)$ & $C(9)-C(10)-C(11)$ & $119.5(5)$ \\
\hline$C(10)-C(11)-C(12)$ & $120.3(6)$ & $C(7)-C(12)-C(11)$ & $120.5(6)$ \\
\hline$N(5)-C(13)-C(14)$ & $117.2(5)$ & $N(5)-C(13)-C(18)$ & $123.0(4)$ \\
\hline$C(14)-C(13)-C(18)$ & $119.8(5)$ & $C(13)-C(14)-C(15)$ & $120.2(5)$ \\
\hline$C(14)-C(15)-C(16)$ & $119.5(4)$ & $C(15)-C(16)-C(17)$ & $120.4(6)$ \\
\hline$C(16)-C(17)-C(18)$ & $120.5(6)$ & $C(13)-C(18)-C(17)$ & $119.6(4)$ \\
\hline
\end{tabular}


larity between the $\mathrm{N}-\mathrm{N}$ distances within each ligand implies a delocalization of the $\pi$-electron in the $\mathrm{N}_{3}$ portion of the ligand. As with the cobalt analogue, $\mathrm{Co}(\mathrm{dpt})_{3},{ }^{7}$ the delocalization could, however, extend to the phenyl rings because the average $\mathrm{N}-\mathrm{C}$ distance (1.410(6) $\AA$ ) is significantly shorter than the $\mathrm{N}-\mathrm{C}$ single bond length of $1.472 \AA{ }^{8}$

It is interesting to note that $\mathrm{Al}(\mathrm{dpt})_{3}$ is the only product to be isolated from the reaction of Hdpt and $\mathrm{AlMe}_{3}$, even when a large excess of $\mathrm{AlMe}_{3}$ is employed. This suggests that the tris-chelate complex is thermodynamically favoured over $\mathrm{AlMe}_{2}(\mathrm{dpt})$ and AlMe(dpt) ${ }_{2}$.

The gallium and indium analogues can be obtained in a similar manner to the aluminium complex, and are spectroscopically equivalent (see Experimental). All three complexes are bright yellow-orange crystalline solids with only limited solubility in non-polar organic solvents, are stable under dry nitrogen at room temperature, but decompose slowly in air, both in solution and the solid state.

\section{EXPERIMENTAL}

Microanalyses were obtained by Oneida Research Services Inc., Whitesboro, New York. Melting points were determined in sealed capillaries and are uncorrected. IR spectra were recorded in the $4000-600 \mathrm{~cm}^{-1}$ region on a Perkin-Elmer 137 grating spectrometer in Nujol mulls. NMR spectra were recorded (in $\mathrm{CDCl}_{3}$ ) on Bruker AM-250 $\left({ }^{1} \mathrm{H}\right)$ and WM-300 $\left({ }^{27} \mathrm{Al}\right)$ spectrometers $[\delta$ in ppm relative to $\mathrm{SiMe}_{4}\left({ }^{1} \mathrm{H}\right)$ and external $\left.\mathrm{Al}\left(\mathrm{H}_{2} \mathrm{O}\right)_{6}^{3+}\left({ }^{27} \mathrm{Al}\right)\right]$. 1,3-Diphenyltriazene was prepared according to published procedures. ${ }^{1}$ All manipulations were carried out under nitrogen. Solvents were distilled and degassed before use.

\section{(1) Tris(1,3-diphenyltriazenido)aluminium(III)}

To a solution of Hdpt $(5.0 \mathrm{~g}, 25.0 \mathrm{mmol})$ in toluene $\left(100 \mathrm{~cm}^{3}\right)$ at room temperature, was added $\mathrm{AlMe}_{3}\left(4.15 \mathrm{~cm}^{3}, 2 \mathrm{M}\right.$ solution in hexane, 8.3 mmol). Immediately following addition, gas was evolved and the solution changed from yellow to orange. After refluxing for $12 \mathrm{~h}$ the solvent was reduced in volume and cooled to give orange crystals. The crystals contained toluene of solvation, which was eliminated by dissolving in pentane and removing the volatiles under vacuum. Yield : 4.04 g, $79 \%$. Melting point: $263^{\circ}$ dec. Found : C, 69.3 ; $\mathrm{H}, 4.14 ; \mathrm{N}, 20.1$. Calc. for $\mathrm{Al}(\mathrm{dpt})_{3}: \mathrm{C}, 70.2 ; \mathrm{H}$, $4.91 ; \mathrm{N}, 20.4 \%$.

'H NMR : $7.49[2 \mathrm{H}, \mathrm{d}, J(\mathrm{H}-\mathrm{H})=9.9 \mathrm{~Hz}, o-\mathrm{H}]$, $7.34[2 \mathrm{H}$, "t", $J(\mathrm{H}-\mathrm{H})=9.3 \mathrm{~Hz}, m-\mathrm{H}], 7.19[1 \mathrm{H}$, $\mathrm{t}, J(\mathrm{H}-\mathrm{H})=8.6 \mathrm{~Hz}, p-\mathrm{H}] .{ }^{27} \mathrm{Al}-\left\{{ }^{1} \mathrm{H}\right\} \mathrm{NMR}:+25$ (br s, $\mathrm{W}_{1 / 2}=1160 \mathrm{~Hz}$ ). IR: $1590 \mathrm{~s}, 1480 \mathrm{~s}, 1320 \mathrm{~m}$, $1295 \mathrm{~s}, 1275 \mathrm{~s}, 1205 \mathrm{~s}, 1170 \mathrm{w}, 1070 \mathrm{w}, 900 \mathrm{w}, 845 \mathrm{w}$, $755 \mathrm{~s}, 680 \mathrm{~s}, 670 \mathrm{~s}$.

\section{(2) Tris(1,3-diphenyltriazenido)gallium(III)}

This complex was prepared as for $\mathrm{Al}(\mathrm{dpt})_{3}$ but using $\mathrm{GaMe}_{3}$ to give a yellow solid. Yield: $45 \%$. Melting point : $243^{\circ} \mathrm{C}$ dec. Found : $\mathrm{C}, 65.2 ; \mathrm{H}, 4.42$; $\mathrm{N}, 18.7$. Calc. for $\mathrm{Ga}(\mathrm{dpt})_{3}: \mathrm{C}, 65.6 ; \mathrm{H}, 4.59 ; \mathrm{N}$, $19.1 \%$.

${ }^{1} \mathrm{H}$ NMR: $[2 \mathrm{H}$, d. $J(\mathrm{H}-\mathrm{H})=8.9 \mathrm{~Hz}, o-\mathrm{H}], 7.35$ [2H, "t", $J(\mathrm{H}-\mathrm{H})=9.1 \mathrm{~Hz}, m-\mathrm{H}], 7.21[1 \mathrm{H}, \mathrm{t}$, $J(\mathrm{H}-\mathrm{H})=8.6 \mathrm{~Hz}, p-\mathrm{H}] . \quad$ IR : $1590 \mathrm{~m}, 1480 \mathrm{~m}$, $1330 \mathrm{sh}, 1300 \mathrm{~s}, 1280 \mathrm{~s}, 1205 \mathrm{~m}, 1155 \mathrm{~m}, 1070 \mathrm{~m}$, $1020 \mathrm{~m}, 900 \mathrm{w}, 795 \mathrm{w}, 755 \mathrm{~m}, 685 \mathrm{w}, 660 \mathrm{w}$.

\section{(3) Tris(1,3-diphenyltriazenido)indium(III)}

This complex was prepared as for $\mathrm{Al}(\mathrm{dpt})_{3}$ but using InMe $\mathrm{In}_{3}$ to give an orange solid. Yield : $62 \%$. Melting point : $244-246^{\circ} \mathrm{C}$ dec. Found : $\mathrm{C}, 61.5 ; \mathrm{H}$, $4.42 ; \mathrm{N}, 17.8$. Calc. for $\operatorname{In}(\mathrm{dpt})_{3}: \mathrm{C}, 61.4 ; \mathrm{H}, 4.31$; $\mathrm{N}, 17.9 \%$.

${ }^{1} \mathrm{H}$ NMR : $7.51[2 \mathrm{H}, \mathrm{d}, J(\mathrm{H}-\mathrm{H})=10.3 \mathrm{~Hz}, o-\mathrm{H}]$, $7.37[2 \mathrm{H}$, " $\mathrm{t}$ ", $J(\mathrm{H}-\mathrm{H})=9.2 \mathrm{~Hz}, m-\mathrm{H}], 7.22[1 \mathrm{H}, \mathrm{t}$, $J(\mathrm{H}-\mathrm{H})=8.4 \mathrm{~Hz}, p-\mathrm{H}] . \mathrm{IR}: 1590 \mathrm{~m}, 1480 \mathrm{~s}, 1325 \mathrm{~s}$, $1310 \mathrm{~s}, 1280 \mathrm{~s}, 1210 \mathrm{w}, 1070 \mathrm{w}, 900 \mathrm{w}, 765 \mathrm{~m}, 690 \mathrm{~m}$, $660 \mathrm{~m}$.

\section{$X$-ray crystallography}

Collection of $X$-ray diffraction data. A light orange crystal of approximate dimensions $0.10 \times 0.23 \times 0.47 \mathrm{~mm}$ was immersed in Paratone$\mathrm{N}$ (lube oil additive), mounted on a glass fiber and transferred to the Syntex $P 2_{1}$ diffractometer, which was equipped with a modified LT-1 apparatus. Subsequent set-up operations (determination of accurate unit cell dimensions and orientation matrix) and collection of low temperature $(213 \mathrm{~K})$ intensity data were carried out using standard techniques similar to those of Churchill et al. ${ }^{9}$ Details are given in Table 2.

All 2587 data were corrected for Lorentz and polarization effects and placed on an approximately absolute scale by means of a Wilson plot. A careful survey of a preliminary data set revealed the systematic extinctions $h k l$ for $h-k=2 n+1$ and $h 0 l$ for $l=2 n+1$; the diffraction symmetry was $2 / m$. Possible space groups are the non-centrosymmetric $C c$ $\left[C_{\mathrm{s}}^{4}:\right.$ No. 9] or the centrosymmetric $C 2 / c\left[C_{2 h}^{6}\right.$; No. 15]. Successful solution and refinement of the structure using the centrosymmetric monoclinic space group $C 2 / c$ later proved it to be the correct choice. 
Table 2. Experimental data for the X-ray diffraction study

\author{
Formula: $\mathrm{C}_{36} \mathrm{H}_{30} \mathrm{~N}_{9} \mathrm{Al} \cdot \mathrm{C}_{7} \mathrm{H}_{8}$ \\ Fw: 707.8 \\ Crystal system: Monoclinic \\ Space group : $C 2 / c$ \\ $a=20.587(3) \AA$ \\ $b=16.005(3) \AA$ \\ $c=13.236(3) \AA$ \\ $\beta=119.172(12)^{\circ}$ \\ $V=3808.1(11) \AA^{3}$ \\ $Z=4$ \\ $D_{\text {calc. }}\left(\mathrm{Mg} \mathrm{m}^{-3}\right)=1.235$ \\ Diffractometer: Syntex $P 2_{1}$ \\ Radiation: $\mathrm{Mo}-K_{\alpha}(\lambda=0.710730 \AA)$ \\ Monochromator: Highly oriented graphite \\ Data collected: $+h,+k, \pm l$ \\ Scan type : $2 \theta-\theta$ \\ Scan width : $1.10^{\circ}$ plus $K$-separation \\ Scan speed : $2.5^{\circ} \min ^{-1}$ (in $\omega$ ) \\ $2 \theta_{\max }\left({ }^{\circ}\right): 45.0$ \\ $\mu\left(\mathrm{Mo}-K_{\alpha}\right)\left(\mathrm{mm}^{-1}\right)=0.092$ \\ Reflections collected : 2587 \\ Reflections with $\left|F_{\mathrm{o}}\right|>3.0 \sigma\left(\left|F_{\mathrm{o}}\right|\right): 2020$ \\ Number of variables : 298 \\ $R_{\mathrm{F}}=6.7 \%$ \\ $R_{\mathrm{wF}}=8.3 \%$
}

Goodness-of-Fit : 2.37

Solution and refinement of the crystal structure. All crystallographic calculations were carried out using either our locally modified version of the UCLA Crystallographic Computing Package ${ }^{10}$ or the SHELXTL PLUS program set. ${ }^{11}$ The analysis, ${ }^{12 a}$ both the real $\left(\Delta f^{\prime}\right)$ and imaginary $\left(i \Delta f^{\prime \prime}\right)$ components of anomalous dispersion ${ }^{12 b}$ were included. The quantity minimized during leastsquares analysis was $\Sigma \mathrm{w}\left(\left|F_{\mathrm{o}}\right|-\left|F_{\mathrm{c}}\right|\right)^{2}$ where $\mathrm{w}^{-1}=\sigma^{2}\left(\left|F_{\mathrm{o}}\right|\right)+0.00046\left(\left|F_{\mathrm{o}}\right|\right)^{2}$.

The structure was solved by direct methods (SHELXTL PLUS); and refined by full-matrix least-squares techniques. Hydrogen atom contributions from the disordered toluene molecule were not included. Refinement of positional and thermal parameters (isotropic for hydrogen atoms and for the carbon atoms of the disordered toluene) led to convergence with $R_{\mathrm{F}}=6.7 \%, R_{\mathrm{wF}}=8.3 \%$ and $\mathrm{G}-\mathrm{O}-\mathrm{F}=2.37$ for 298 variables refined against those 2020 data with $\left|F_{\mathrm{o}}\right|>3.0 \sigma\left(\left|F_{\mathrm{o}}\right|\right)$. A final difference-Fourier map was "clean", $\rho(\max )=1.01$ e $\AA^{-3}$. Atomic coordinates have been deposited with the Cambridge Crystallographic Data Centre.

Acknowledgements - Funds for the purchase of the Nicolet $\mathrm{R} 3 \mathrm{~m} / \mathrm{V}$ diffractometer system were made available from the National Science Foundation under Grant CHE-85-14495. J.T.L. is a Joshiah Parsons Cooke Fellow, 1988-1989.

\section{REFERENCES}

1. D. S. Moore and S. D. Robinson, Adv. Inorg. Chem. Radio. Chem. 1986, 30, 1.

2. M. J. Taylor, in Comprehensive Coordination Chemistry (Edited by G. Wilkinson, R. D. Gillard and J. A. McCleverty), Vol. 3. Pergamon Press, Oxford (1988).

3. D. St. C. Black, V. C. Davis, G. B. Deacon and R. J. Schultze, Inorg. Chim. Acta 1979, 37, L528.

4. J. Beck and J. Strahle, Z. Naturfor. 1986, 41B, 1381.

5. R. K. Harris and B. E. Mann, NMR and the Periodic Table. Academic Press, London (1978).

6. G. H. Robinson, H. Zhang and J. L. Atwood, J. Organomet. Chem. 1987, 331, 153, and refs therein.

7. (a) M. Corbett and B. F. Hoskins, J. Am. Chem. Soc. $1967,89,1530$; (b) W. R. Krigbaum and B. Rubin, Acta Cryst. 1973, B29, 749.

8. L. E. Sulton, Interatomic Distances and Configuration in Molecules and Ions, Special Publications No. 18. The Chemical Society, London (1965).

9. M. R. Churchill, R. A. Lashewycz and F. J. Rotella, Inorg. Chem. 1977, 16, 265.

10. UCLA Crystallographic Computing Package. University of California, Los Angeles (1981); C. Strouse, personal communication.

11. Nicolet Instrument Corporation, Madison, Wisconsin (1988).

12. International Tables for $X$-Ray Crystallography, (a) pp. 99-101 ; (b) pp. 149-150. Kynoch Press, Birmingham, U.K. (1974). 